\title{
Phenology of Some Phanerogams (Trees and Shrubs) of Northwestern Punjab, India
}

\author{
Gurveen Kaur, Bhupinder Pal Singh, and Avinash Kaur Nagpal \\ Department of Botanical and Environmental Sciences, Guru Nanak Dev University, Amritsar 143005, India \\ Correspondence should be addressed to Gurveen Kaur; bajwagurveen@gmail.com and \\ Avinash Kaur Nagpal; avnagpal.dobes@gndu.ac.in
}

Received 23 January 2013; Revised 26 April 2013; Accepted 19 May 2013

Academic Editor: William K. Smith

Copyright (c) 2013 Gurveen Kaur et al. This is an open access article distributed under the Creative Commons Attribution License, which permits unrestricted use, distribution, and reproduction in any medium, provided the original work is properly cited.

Plants perform various vegetative and reproductive functions throughout the year in order to persist in their habitats. The study of these events including their timing and how the environment influences the timing of these events is known as phenology. This study of the timing of seasonal biological activities of plants is very important to know about plant's survival and its reproductive success. The variation in the phenological activities is due to change in different abiotic conditions. This paper deals with the study of phenological activities like bud formation, flowering time, fruiting time, and seed formation for some leguminous plants of Amritsar, Punjab (a state in the northwest of India) for three consecutive years from 2009 till 2011.

\section{Introduction}

The timing of various phenological activities such as germination, bud break, flowering, fruit dehiscence, and leaf drop is important for survival and reproductive success of many plant species. Abiotic environmental conditions such as rain, change in temperature, presence/absence of pollinators, competitors, and herbivores have been shown to play a significant role in timing of various phenological events [1-6]. Natural selection has also been considered to play some role in determining the phenological patterns of plant species [7]. Phenological studies are also important in understanding species interrelations and their interaction with the environment. Variations in phenophases among individuals of the same species or different species have been linked to environmental perturbations [8].

Considerable amount of phenological data is available on different plant species from different parts of the world including tropical savanna and semideciduous forest of Venezuelan Ilanos (South America) [9], dry tropical forest in Ghana [10], NE Spain [11-13], Panama [14], Mexico [15], tropical rain forest in Malaya [16], semiarid grassland in the Rock mountain, USA [17], and tibetan plateau [18].

A number of studies on phenology of different plant species from different parts of India have also been undertaken which include those from a subtropical humid forest in North-Eastern India [19, 20], Kumaun Himalayan forests [21, 22], deciduous forest of Bandipur in peninsular India [23], Shervaroys, Southern India [24], tropical moist forest of Western Ghats in Karnataka [25], Hathinala Forest in Uttar Pradesh [26], alpine expanse of North-West Himalaya [27], Orissa coast [28], tropical montane forests in the Nilgiris [8], Kolhapur region (Maharashtra) [29], and Katerniaghat wildlife sanctuary situated in the Himalayan Terai region in Uttar Pradesh [30], Northeastern India [31]. However, no such information is available on plants of Punjab plains, hence we initiated phenological studies in trees and shrubs of this region of India. To begin with, we have compiled information on fifteen leguminous species from Amritsar.

The family leguminosae is a large and economically important family of flowering plants and has traditionally been divided into three subfamilies Papilionoideae (Faboideae), Caesalpinioideae, and Mimosoideae. These have been recognized as independent families Fabaceae (Papilionaceae), Caesalpiniaceae, and Mimosaceae in several recent systems of classification.

The present paper deals with phenological observations of fifteen leguminous plants growing at four different sites in Amritsar over a period of three years from 2009 till 2011 as these sites represent most of the plant diversity of this region. 


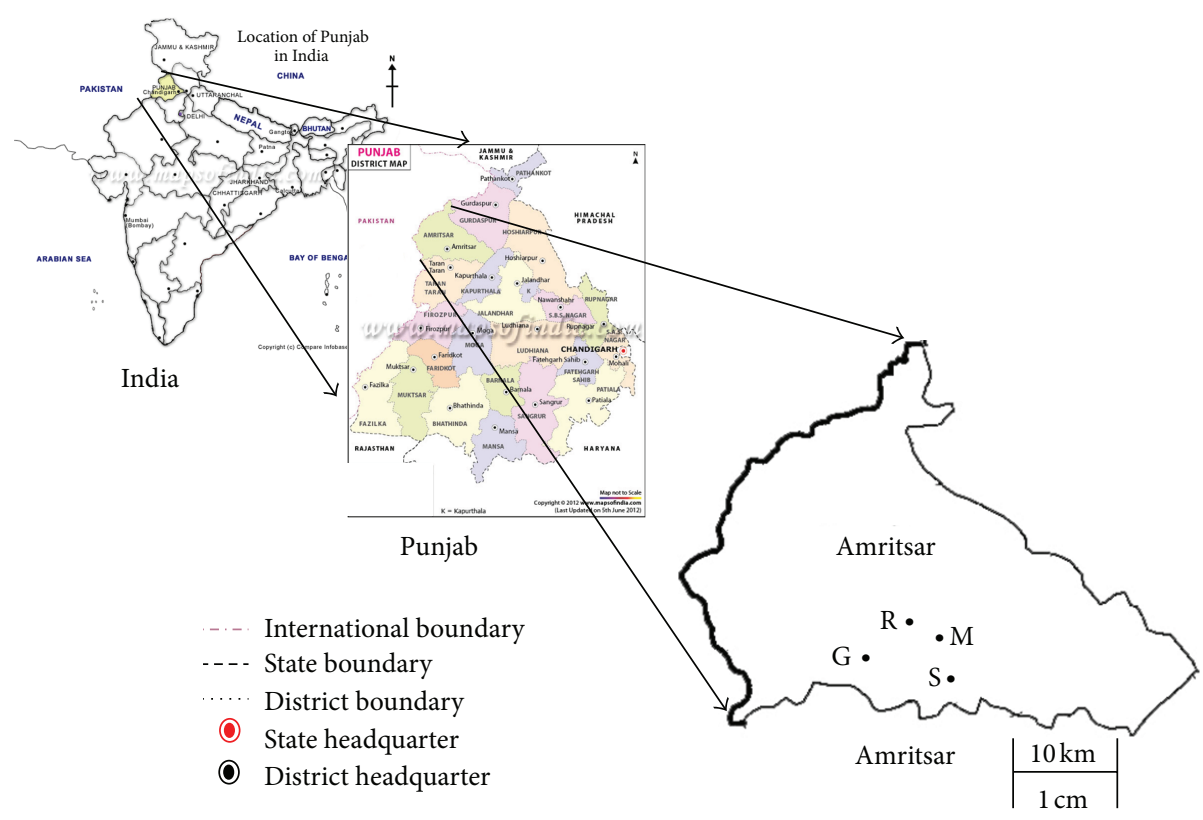

Figure 1: Amritsar, the Northwestern part of India. G: Guru Nanak Dev University; S: Sakatri Bagh; M: Maharaja Ranjit Singh Park; R: Ranjit Avenue.

\section{Materials and Methods}

2.1. Study Area. The Amritsar district is located in northwestern part of the Punjab state and lies between $31^{\circ} 28^{\prime} 30^{\prime \prime}$ to $32^{\circ} 03^{\prime} 15^{\prime \prime}$ north latitude and $74^{\circ} 29^{\prime} 30^{\prime \prime}$ to $75^{\circ} 24^{\prime} 15^{\prime \prime}$ east longitude. Total area of the district is $5056 \mathrm{~km}^{2}$ with tropical dry deciduous type of vegetation [32]. Natural vegetation is fragmented and is at present available only in narrow strips and patterns.

Amritsar has a semiarid climate, typical of northwestern India and experiences four seasons primarily:

(i) winter season (December to February) with temperature ranges from $4^{\circ} \mathrm{C}\left(39^{\circ} \mathrm{F}\right)$ to about $19^{\circ} \mathrm{C}\left(66^{\circ} \mathrm{F}\right)$;

(ii) summer season (April to June) where temperatures can reach $45^{\circ} \mathrm{C}\left(113^{\circ} \mathrm{F}\right)$;

(iii) monsoon season (July to September);

(iv) postmonsoon season (September to October).

There is a transitional period between winter and summer in March and early April (called as spring), as well as a transitional season between postmonsoon season and winter in October and November (called as autumn). Annual rainfall in Amritsar is about 680 millimetres (ground water information booklet, Amritsar district, Punjab by Central Ground Water Board, Ministry of Water Resources, Government of India, north western region, Chandigarh).

The whole area of Amritsar was surveyed and four different sampling sites, that is, Guru Nanak Dev University (G), Sakatri Bagh (S), Maharaja Ranjit Singh Park (M), and Ranjit Avenue (R) were selected for data collection. These sites were chosen as they represent most of the plant diversity of Amritsar. Figure 1 shows the location of four sites on the map of Amritsar. The maps were downloaded from Maps of India and Google images, and the climatic data of Amritsar was obtained from the wunderground website (http://www .wunderground.com/). This weather station (VIAR) is located at Raja Sansi International Airpot, Amritsar at an elevation of $234 \mathrm{~m}$. Table 1 shows the minimum, mean, and maximum temperature values from January to December for three consecutive years from 2009 to 2011 of Amritsar.

Table 2 lists fifteen plant species selected for the present study along with their family, sampling site, growth form, and leaf habit. The data for each species was collected from a minimum of two sampling sites mentioned in Table 2. At each site, one mature and healthy plant from the population of that species was fixed as reference for the study. The observations were made on the marked plant and 10-15 of its closest neighbours (minimum 6 plants if more plants were not available for a particular plant species at a particular site) for a period of 3 years starting from January 2009 up to December, 2011. This selection regime was based on a study by Pilar and Gabriel [12]. The areas with the plants under study were visited daily to record presence/absence of different phenological events or phenophases: flower bud formation (B), flowering (FL), fruit setting (FR), and seed set and dispersal (S). The information for the initial date and the last date when these various phenophases were observed was recorded. A phenophase was considered to be active in the population just when it was observed in at least $5 \%$ of the crown in a minimum of $20 \%$ of the studied plants [12]. Phenophase calendars for each species were prepared and were studied for the interpretation of the overall results. For the whole set of studied species, the frequency of occurrence of different phenophases in each month was calculated.

\section{Results}

The results on percentage of 15 plant species taken all together showing timing of different phenophases (Buds, Flowers, 
TABLE 1: Monthly minimum, mean, and maximum temperature in Amritsar for the years 2009, 2010, and 2011.

\begin{tabular}{|c|c|c|c|c|c|c|c|c|c|}
\hline & \multicolumn{3}{|c|}{2009} & \multicolumn{3}{|c|}{2010} & \multicolumn{3}{|c|}{2011} \\
\hline & Min. & Mean & Max. & Min. & Mean & Max. & Min. & Mean & Max. \\
\hline Jan. & 6 & 12 & 18 & 3 & 8 & 14 & 5 & 10 & 16 \\
\hline Feb. & 9 & 16 & 23 & 10 & 16 & 22 & 9 & 14 & 20 \\
\hline Mar. & 12 & 20 & 27 & 16 & 23 & 30 & 13 & 20 & 27 \\
\hline Apr. & 18 & 26 & 34 & 21 & 30 & 38 & 17 & 25 & 33 \\
\hline May & 23 & 31 & 39 & 25 & 32 & 40 & 25 & 32 & 40 \\
\hline Jun. & 25 & 33 & 41 & 26 & 32 & 39 & 26 & 31 & 37 \\
\hline Jul. & 26 & 31 & 36 & 27 & 31 & 34 & 27 & 30 & 34 \\
\hline Aug. & 27 & 30 & 35 & 26 & 29 & 33 & 26 & 29 & 32 \\
\hline Sep. & 23 & 28 & 33 & 24 & 28 & 32 & 25 & 28 & 32 \\
\hline Oct. & 21 & 26 & 32 & 20 & 25 & 31 & 18 & 25 & 32 \\
\hline Nov. & 11 & 18 & 24 & 12 & 19 & 27 & 13 & 20 & 27 \\
\hline Dec. & 5 & 13 & 21 & 5 & 12 & 20 & 6 & 13 & 21 \\
\hline
\end{tabular}

TABLE 2: List of plant species studied with their abbreviation, family, sampling site, growth form (T: tree; S: shrub; C: climber) and leaf habit (E: evergreen and D: deciduous).

\begin{tabular}{|c|c|c|c|c|c|c|}
\hline S. No. & Species & Abbreviation & Family & Sampling site ${ }^{*}$ & Growth form & Leaf habit \\
\hline 1 & Bauhinia variegata Linn. & Bva & Caesalpiniaceae & $\mathrm{G}, \mathrm{S}, \mathrm{M}, \mathrm{R}$ & $\mathrm{T}$ & $\mathrm{D}$ \\
\hline 2 & Caesalpinia pulcherrima (Linn.) Sw. & $\mathrm{Cpu}$ & Caesalpiniaceae & $\mathrm{G}, \mathrm{M}, \mathrm{R}$ & S & $\mathrm{E}$ \\
\hline 3 & Cassia fistula Linn. & Cfi & Caesalpiniaceae & $\mathrm{G}, \mathrm{S}, \mathrm{M}, \mathrm{R}$ & $\mathrm{T}$ & $\mathrm{D}$ \\
\hline 4 & Cassia glauca Lam. & $\mathrm{Cgl}$ & Caesalpiniaceae & $\mathrm{G}, \mathrm{S}, \mathrm{R}$ & S & $\mathrm{E}$ \\
\hline 5 & Cassia siamea Lamk. & Csi & Caesalpiniaceae & $\mathrm{G}, \mathrm{R}$ & $\mathrm{T}$ & $\mathrm{E}$ \\
\hline 6 & Delonix regia Rafin. & Dre & Caesalpiniaceae & $\mathrm{G}, \mathrm{S}, \mathrm{M}$ & $\mathrm{T}$ & $\mathrm{D}$ \\
\hline 7 & Parkinsonia aculeata Linn. & $\mathrm{Pac}$ & Caesalpiniaceae & $\mathrm{G}, \mathrm{R}$ & $\mathrm{T}$ & $\mathrm{D}$ \\
\hline 8 & Acacia auriculiformis A. Cunn. & Aau & Mimosaceae & $\mathrm{G}, \mathrm{M}, \mathrm{R}$ & $\mathrm{T}$ & $\mathrm{E}$ \\
\hline 9 & Acacia nilotica Delile & Ani & Mimosaceae & $\mathrm{G}, \mathrm{R}$ & $\mathrm{T}$ & $\mathrm{E}$ \\
\hline 10 & Albizia lebbeck Benth. & Ale & Mimosaceae & $\mathrm{G}, \mathrm{S}$ & $\mathrm{T}$ & $\mathrm{D}$ \\
\hline 11 & Calliandra tweedii Benth. & Ctw & Mimosaceae & $\mathrm{G}, \mathrm{R}$ & $\mathrm{S}$ & $\mathrm{E}$ \\
\hline 12 & Prosopis juliflora DC. & Pju & Mimosaceae & $\mathrm{G}, \mathrm{S}, \mathrm{M}$ & $\mathrm{T}$ & $\mathrm{E}$ \\
\hline 13 & Abrus precatorius Linn. & Ape & Papilionaceae & $\mathrm{G}, \mathrm{S}, \mathrm{R}$ & $\mathrm{C}$ & $\mathrm{D}$ \\
\hline 14 & Butea monosperma (Lam.) Kuntze & Bmo & Papilionaceae & $\mathrm{G}, \mathrm{R}$ & $\mathrm{T}$ & $\mathrm{D}$ \\
\hline 15 & Dalbergia sissoo Roxb. & Dsi & Papilionaceae & $\mathrm{G}, \mathrm{S}, \mathrm{M}, \mathrm{R}$ & $\mathrm{T}$ & $\mathrm{D}$ \\
\hline
\end{tabular}

* Sampling sites shown in Figure 1.

Fruits, and Seeds) during the study period are shown in Figure 2. This figure reveals that percentage of plant species exhibiting each phenophase, that is, buds, flowers, fruits, and seeds showed almost a similar trend for three consecutive years within each phenophase. Bud formation showed a peak in the beginning of summer (60\%) and another small peak during late monsoon and was almost evenly distributed through the rest of the year for all the three years. Similar trend was observed for flowering which also showed a peak (66.67\%) during beginning of summer and another small peak $(53.33 \%)$ during postmonsoon period for all the three years. Maximum percentage of plant species showing fruiting was observed in the months of March, April, and May (60\%) which resulted in maximum seed set in the months of June, July, and August during the study period. Comparison of results on observations of flowering in different plant species during the three consecutive years 2009, 2010, and 2011, reveals that maximum percentage of plant species (66.67\%) showing flowering was observed in the month of April during 2011.
Figure 3 shows phenological patterns of individual plant species studied. For each plant species, the whole period of appearance of different phenophases-like bud formation, flowering, fruiting, and seed set has been indicated for three consecutive years. The study reveals high phonological diversity for different phenophases studied among fifteen plant species. However, for individuals of the same species, no differences in the appearance of different phenophases were observed.

During the study period, it was observed that some species like Bauhinia variegata Linn., Caesalpinia pulcherrima (Linn.) Sw., Cassia glauca Lam., Cassia siamea Lamk., and so forth showed conspicuous buds (2-4 weeks) before flowering, but in case of Dalbergia sissoo Roxb bud formation was observed just few days (less than a week) before prominent flowering was recorded. Most of the species flowered from spring to late summer (e.g., Parkinsonia aculeata Linn. and Acacia auriculiformis A. Cunn.). Butea monosperma (Lam.) Kuntze exhibited flowering during the monsoon and postmonsoon period only. Some of the species that showed 


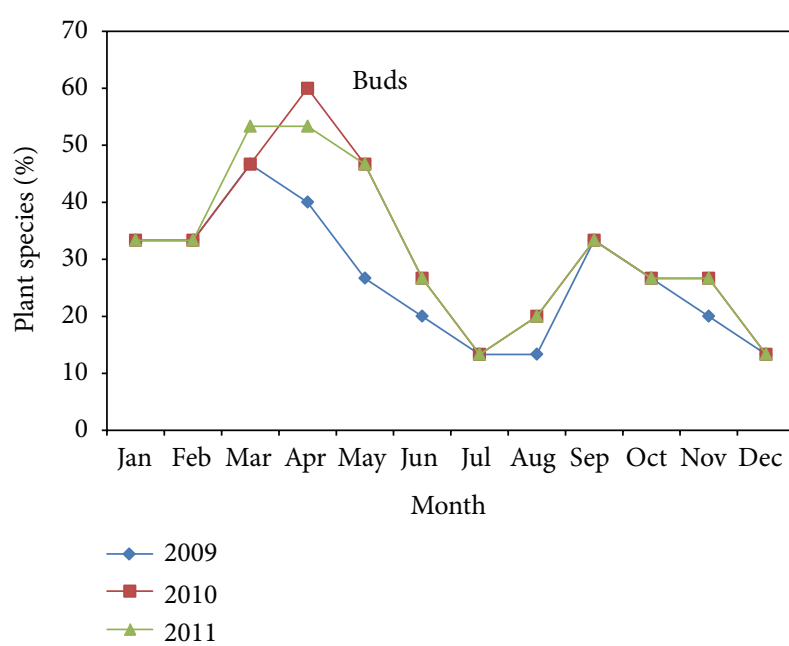

(a)

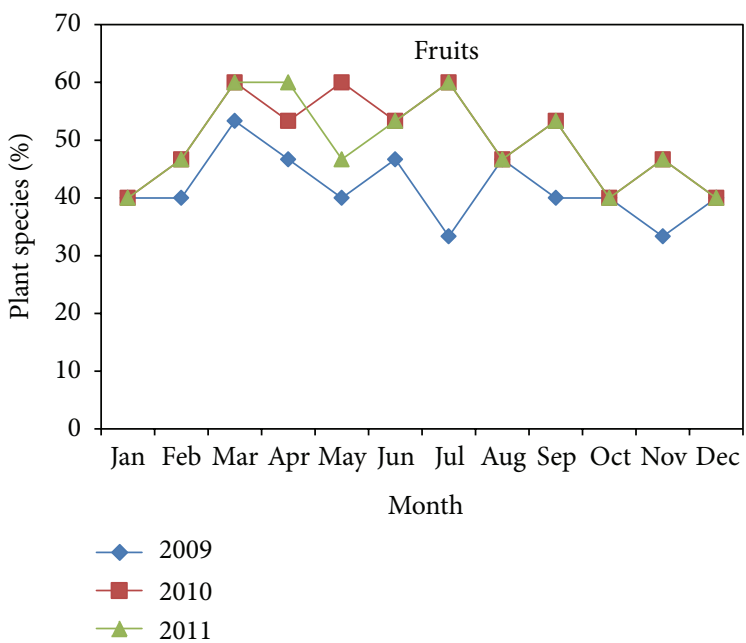

(c)

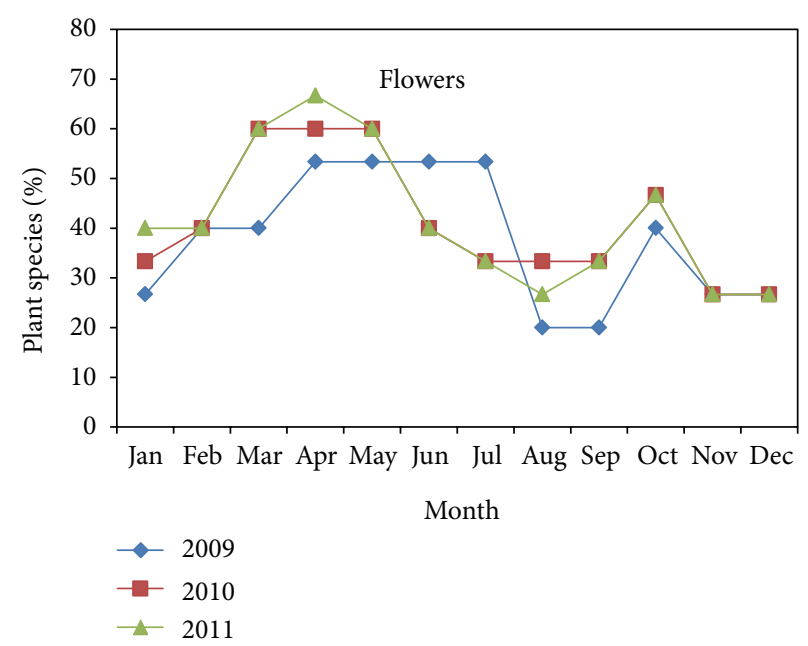

(b)

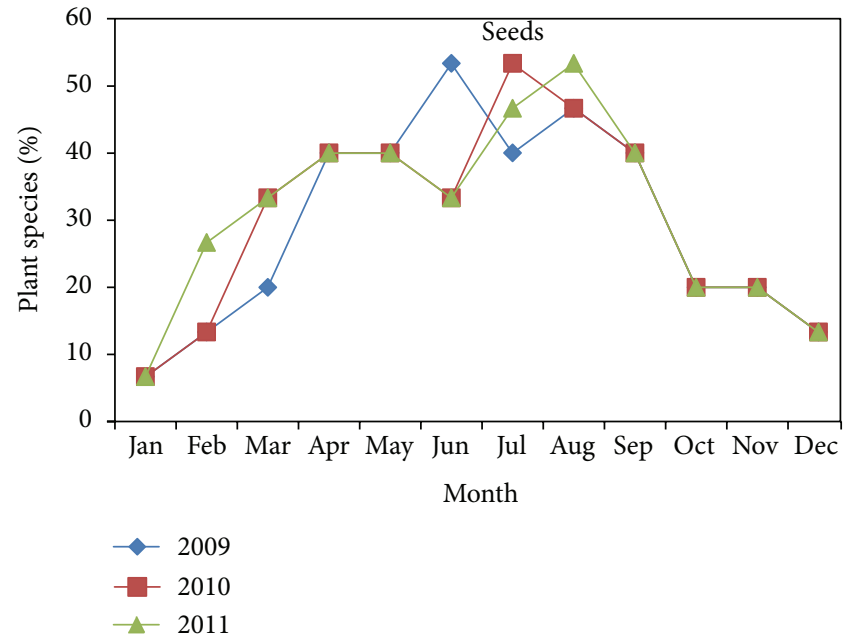

(d)

FIGURE 2: Percentage of plant species under study showing each phenophase: buds (a), flowers (b), fruits (c), and seeds (d) during 2009 to 2011.

flowering during winter months extending to early summer included Caesalpinia pulcherrima (Linn.) Sw., Cassia siamea Lamk., and Delonix regia Rafin. Variation in the flowering time period was observed for different species ranging from 2 months (Abrus precatorius Linn.) to 7 months (Cassia glauca Lam.). Similarly the variation in fruiting period was observed from 3 months as in the case of Cassia siamea Lamk., and so forth, to have fruiting almost throughout the year as for Dalbergia sissoo Roxb. By the end of summer, the seeds of most of the plant species were mature and ready for dispersal. There were two time periods in the year when leaf shedding was observed, that is, in summer and in the autumn depending on the type of leaf habit of that plant species.

\section{Discussion}

Our study reveals high phenological diversity for the four phenological patterns (buds, flowers, fruits, and seeds) among fifteen leguminous plant species growing in Amritsar under similar environmental conditions for the three consecutive years, that is, 2009, 2010, and 2011. Changes in plant phenological patterns have been associated with the species specific plant structural architecture, availability and transfer of nutrients [33], plant growth rates [34], temperature [35], and water [36].

A comparison of observations on flowering time for the three years under study reveals an advancement of flowering time by about 2-4 weeks in the year 2010 for some species like Acacia nilotica Delile, Abrus precatorius Linn., Bauhinia variegata Linn., Dalbergia sissoo Roxb., Delonix regia Rafin., and Parkinsonia aculeata Linn. as compared to that observed in 2009 (Figure 3). This change in phenological shift can be attributed to increase in temperature in 2010 as compared to that reported for 2009 (Table 1). The total length of flowering period was extended by $2-4$ weeks in 2010-11 as compared to 2009 for species like Bauhinia variegata Linn., Caesalpinia pulcherrima (Linn.) Sw., Cassia fistula Linn., Parkinsonia aculeata Linn., Acacia nilotica Delile, Calliandra tweedii Benth., and Prosopis juliflora DC. 


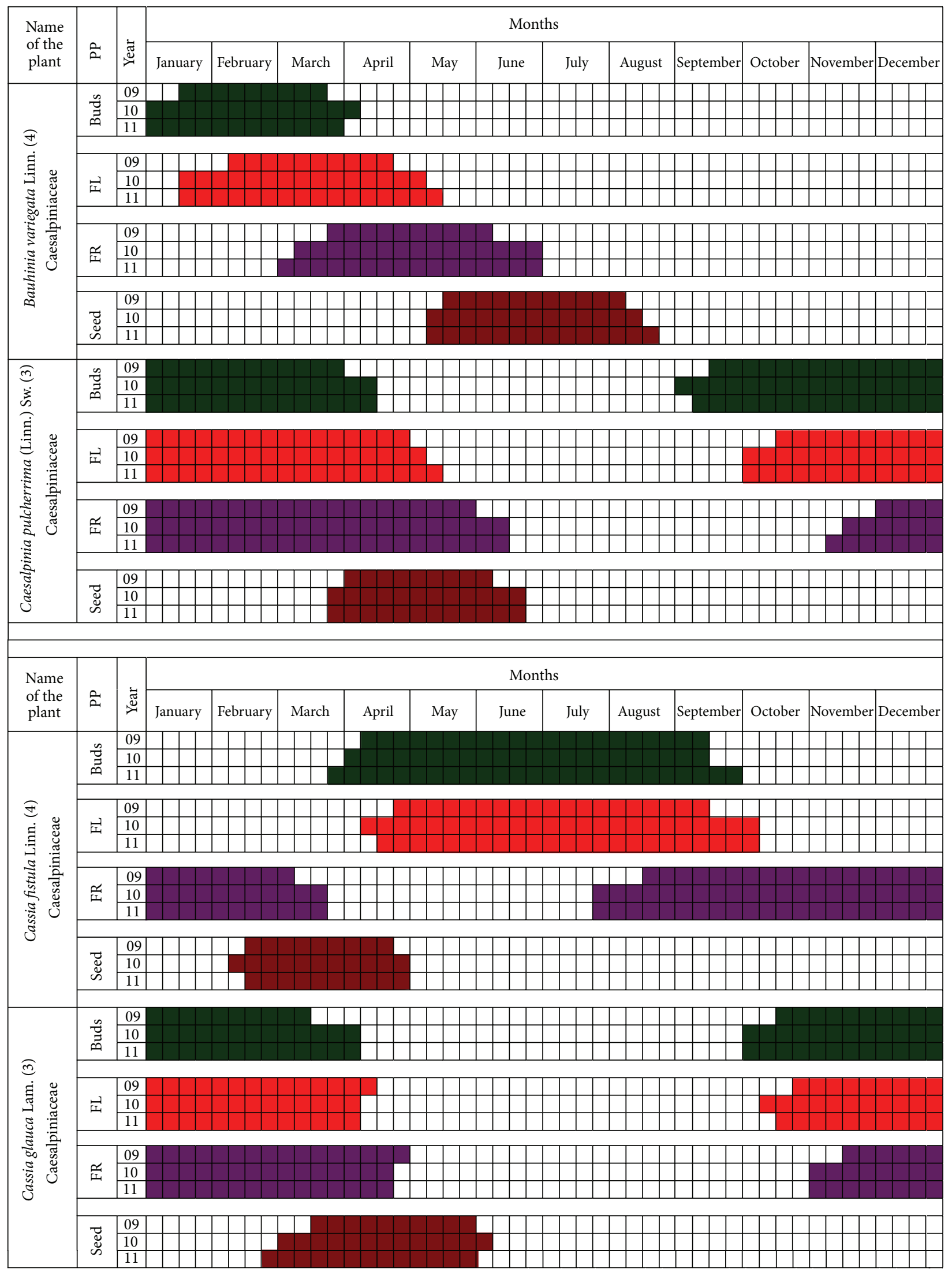

Figure 3: Continued. 


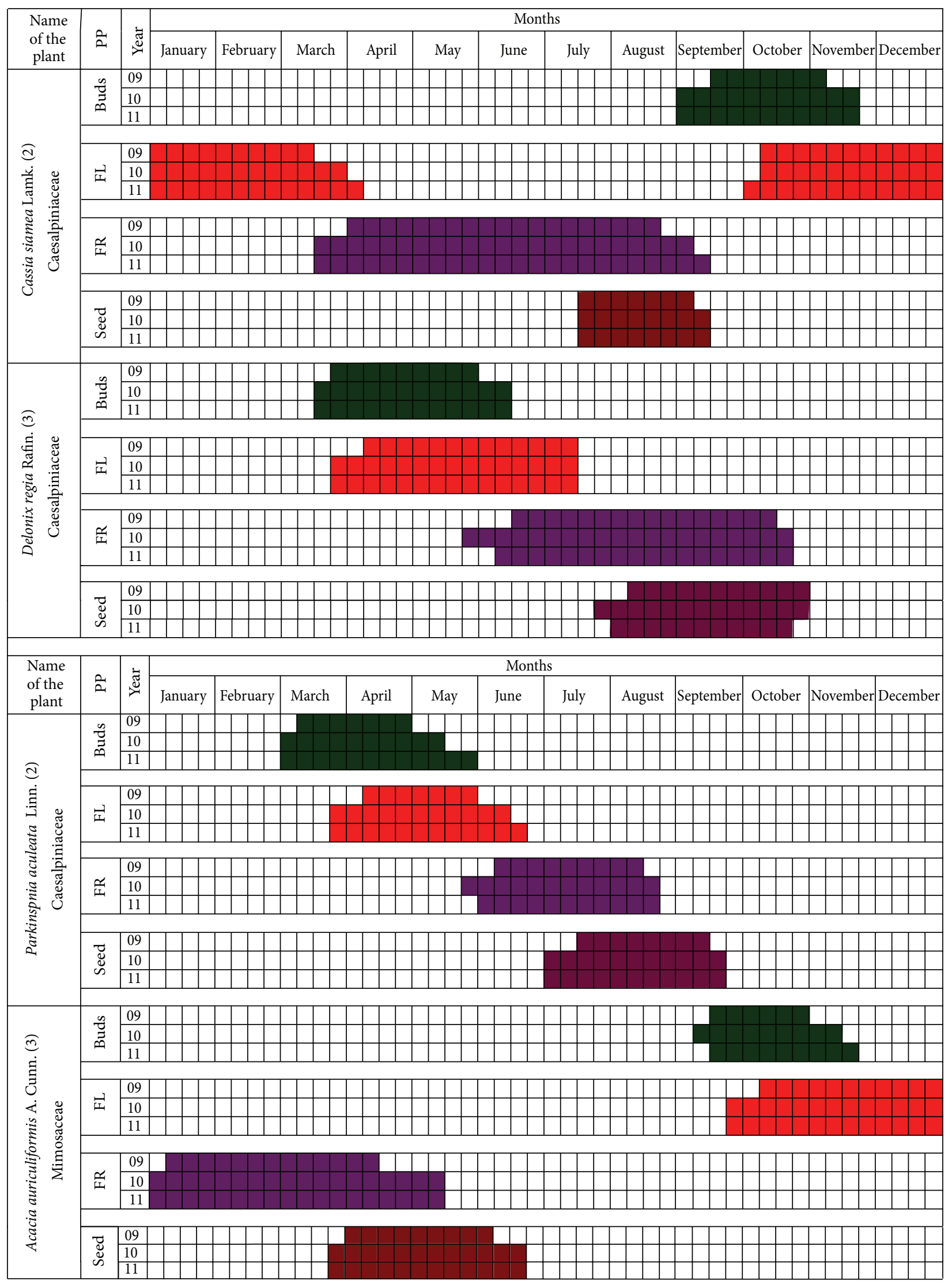

FIGURE 3: Continued. 


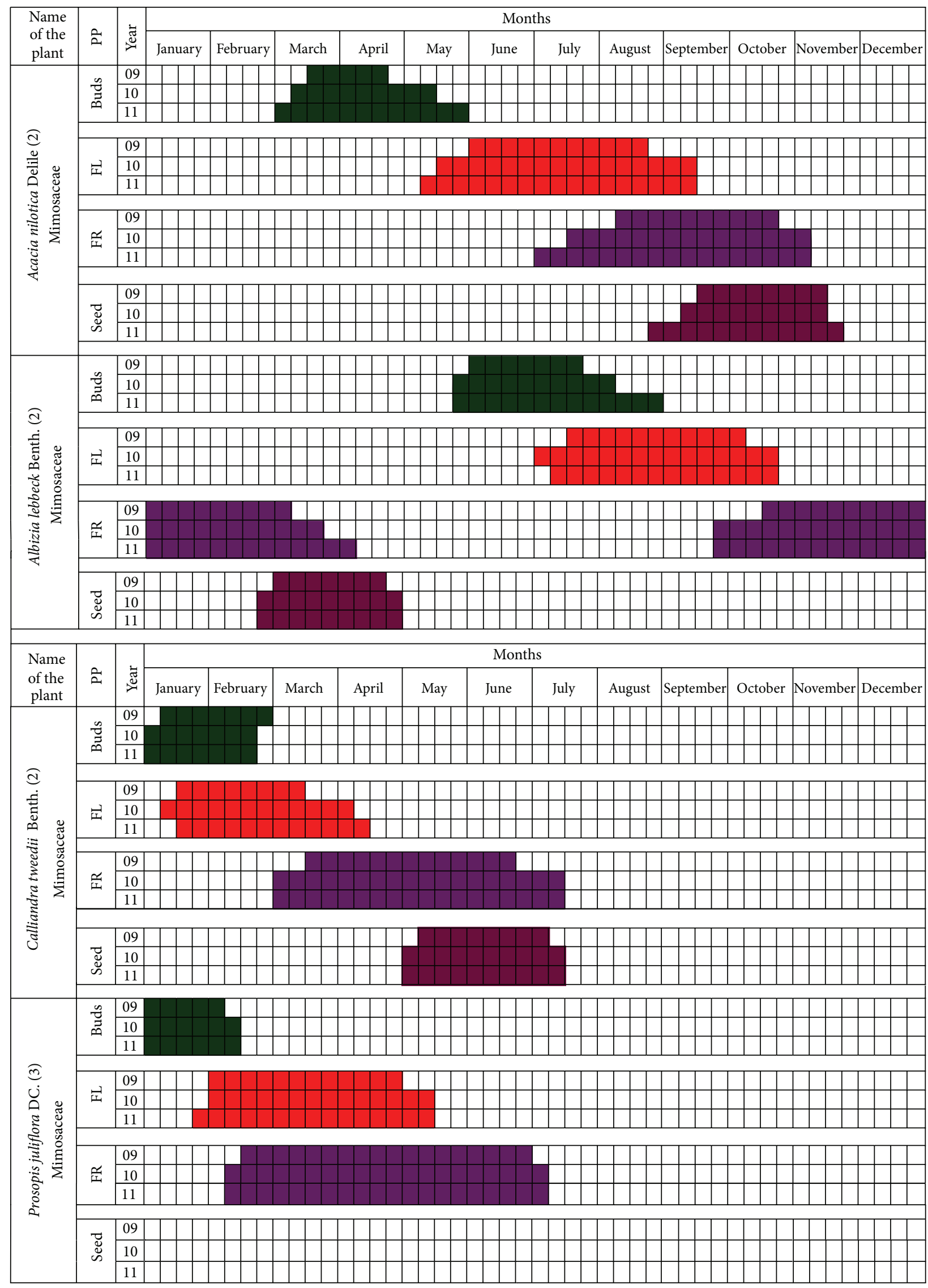




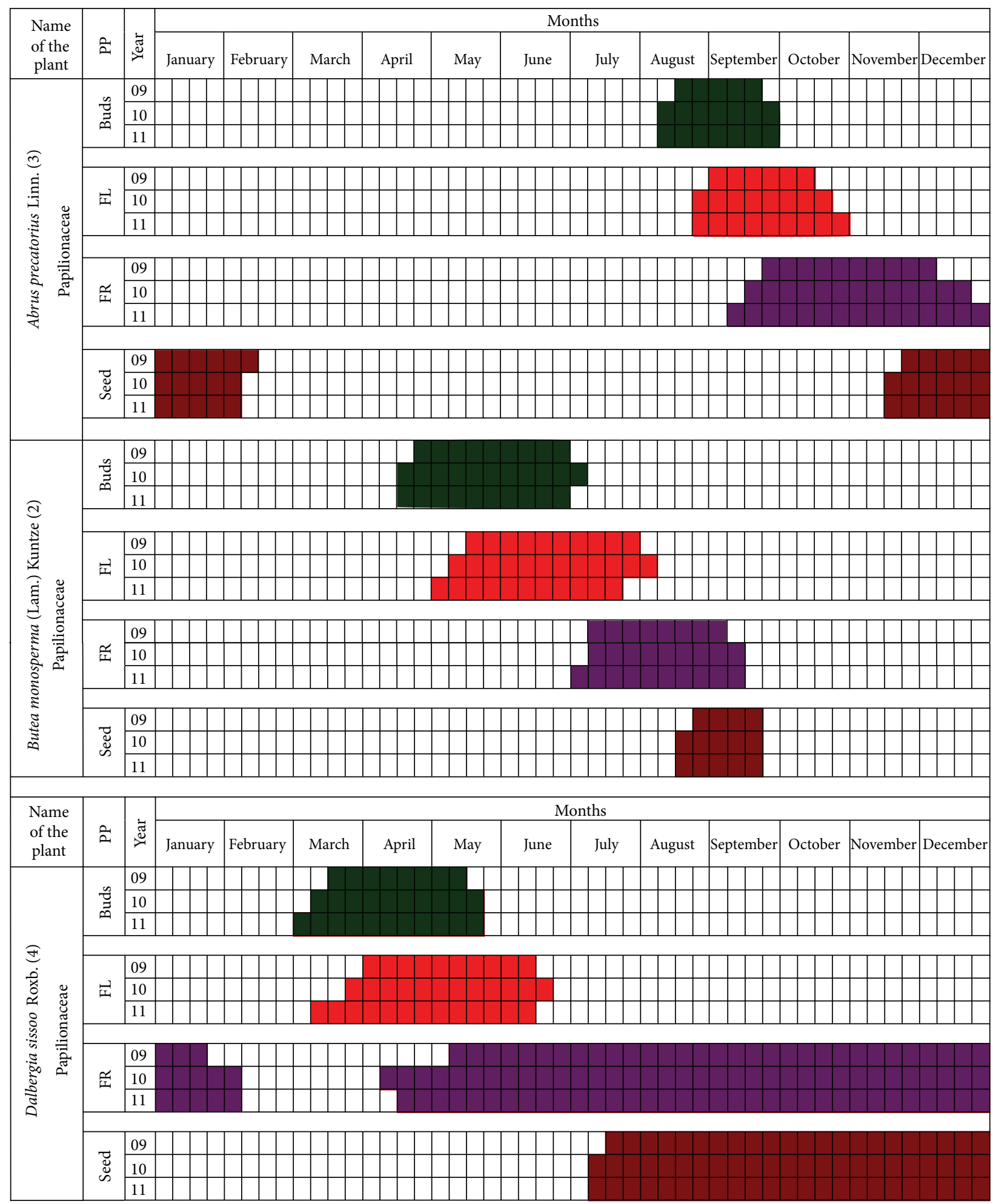

Figure 3: Phenological diagrams of fifteen plant species belonging to families caesalpiniaceae, mimosaceae, and papilionaceae. The dark colored bars indicate the whole period of appearance of different phenophases including buds: bud formation; FL: flowering; FR: fruiting, and seed: seed formation for three consecutive years. Numbers in parenthesis beside the species names are the number of considered populations. (PP: phenophase). 
Some other studies have also demonstrated an association of an advancement in flowering date with climate change. One study has reported an increase in the mean terrestrial surface temperature by more than $0.2^{\circ} \mathrm{C}$ per decade ever since 1970 [37]. A number of other studies have shown an advancement of phenological events as a result of increase in temperature [38-41]. With the increase in the temperature, most of the species showed earlier flowering time period [39] and even increase in their time period of flowering (e.g., Bauhinia variegate Linn., Prosopis juliflora DC.). Similarly early flowering was observed for 24 out of the 32 plant species studied in a semiarid grassland by Lesica and Kittelson [17].

The period of maximum activity of bud formation in the months of spring and the flowering period (started in spring and extended to summer and the beginning of autumn) coincided with the observations of Pilar and Gabriel [12]. Flower development dates have been shown to be synchronous among individuals of the same plant species studied which seems to be important in increasing the chances of outcross pollinations as suggested by Ollerton and Lack [42].

These changes in the phenological patterns can result in adverse effects on insect pollinators as well as herbivores (if the plant species is present in barren or wild areas) that depend on those species for food $[43,44]$. The changes in phenological patterns of plant's response to different temperature and rainfall availability have been shown to be species specific $[45,46]$. Hence changes in vegetation community species composition might also be responsible for changes in the phenology of the studied plants. The present study reveals that different plants of the same family (Leguminosae) flower at different times during the same year growing at same location under similar environmental conditions which can be attributed to species-specific plant structural architecture.

\section{Conclusion}

The present study reveals high phenological diversity for four different phenophases among fifteen leguminous plant species growing in Amritsar with tropical dry deciduous type of vegetation. This study would be of great help in knowing the timing of different phenophases of the studied plants which can be of interest to people of this region (or where similar climatic conditions prevail) who wish to plan their gardens and wish to have flowers in their gardens round the year. So, they can select plants which flower during different parts of the year. This type of study can provide important insights into the biology of the plants concerned and reveal phenological pattern of surveyed species. This study would also be of great help for comparison over long duration of time. For example, to see if there is any change in the phenological patterns of the same plant species in next 10 or so years. Such comparative study could not be possible at this time since no relevant literature is available for this region.

\section{Acknowledgment}

The authors thank Department of Science and Technology, Government of India, for INSPIRE Fellowship to Ms. Gurveen Kaur.

\section{References}

[1] E. R. Heithaus, "The role of plant-pollinator interactions in determining community structure," Annals of the Missouri Botanical Garden, vol. 61, pp. 675-691, 1974.

[2] G. W. Frankie, "Tropical forest phenology and pollinator plant coevolution," in Coevolution of Animals and Plants, L. E. Gilbert and P. H. Raven, Eds., pp. 192-209, University of Texas Press, Austin, Tex, USA, 1975.

[3] H. R. Pulliam and M. R. Brand, "The production and utilization of seeds in plains grassland of southeastern Arizona," Ecology, vol. 56, pp. 1158-1166, 1975.

[4] P. A. Opler, G. W. Frankie, and H. G. Baker, "Rainfall as a factor in the release, timing and synchronization of anthesis by tropical trees and shrubs," Journal of Biogeography, vol. 3, pp. 231-236, 1976.

[5] J. N. Thompson and M. F. Willson, "Evolution of temperature fruit/bird interactions: phenological strategies," Evolution, vol. 33, pp. 973-982, 1979.

[6] E. W. Stiles, "Patterns of fruit presentation and seed dispersal in bird disseminated woody plants in the eastern deciduous forest," The American Naturalist, vol. 116, pp. 670-688, 1980.

[7] G. F. Estabrook, J. A. Winsor, A. G. Stephenson, and H. F. Howe, "When are two phenological patterns different?" Botanical Gazette, vol. 143, no. 3, pp. 374-378, 1982.

[8] H. S. Suresh and R. Sukumar, "Vegetative phenology of tropical montane forests in the Nilgiris, South India," Journal of the National Science Foundation of Sri Lanka, vol. 39, no. 4, pp. 333343, 2011.

[9] M. Monasterio and G. Sarmiento, "Phenological strategies of plant species in the tropical savanna and the semideciduous forest of the Venezuelan Ilanos," Journal of Biogeography, vol. 3, pp. 352-356, 1976.

[10] D. Lieberman, "Seasonality and phenology in a dry tropical forest in Ghana," Journal of Ecology, vol. 70, no. 3, pp. 791-806, 1982.

[11] R. Milla, P. Castro-Díez, and G. Montserrat-Martí, "Phenology of Mediterranean woody plants from NE Spain: synchrony, seasonality, and relationships among phenophases," Flora, vol. 205, no. 3, pp. 190-199, 2010.

[12] C.-D. Pilar and M.-M. Gabriel, "Phenological pattern of fifteen Mediterranean phanaerophytes from Quercus ilex communities of NE-Spain," Plant Ecology, vol. 139, no. 1, pp. 103-112, 1998.

[13] G. Montserrat-Martí and C. Pérez-Rontomé, "Fruit growth dynamics and their effects on the phenological pattern of native Pistacia populations in NE Spain," Flora, vol. 197, no. 3, pp. 161$174,2002$.

[14] D. De Steven, D. M. Windsor, and F. E. Putz, "Vegetative and reproductive phonologies of a palm assemblage in Panama," Biotropica, vol. 19, pp. 342-356, 1987.

[15] S. H. Bullock and J. A. Solis-Magallanes, "Phenology of canopy trees of a tropical deciduous forest in Mexico," Biotropica, vol. 22, pp. 22-35, 1990.

[16] L. Medway, "Phenology of a tropical rain forest in Malaya," Biological Journal of the Linnean Society, vol. 4, no. 2, pp. 117$146,1972$.

[17] P. Lesica and P. M. Kittelson, "Precipitation and temperature are associated with advanced flowering phenology in a semi-arid grassland," Journal of Arid Environments, vol. 74, pp. 1013-1017, 2010. 
[18] M. Shen, Y. Tang, J. Chen, X. Zhu, and Y. Zheng, "Influences of temperature and precipitation before the growing season on spring phenology in grasslands of the central and eastern Qinghai-Tibetan Plateau," Agricultural and Forest Meteorology, vol. 151, no. 12, pp. 1711-1722, 2011.

[19] R. P. Shukla and P. S. Ramakrishnan, "Phenology of trees in a sub-tropical humid forest in north-eastern India," Vegetatio, vol. 49, no. 2, pp. 103-109, 1982.

[20] R. P. Shukla and P. S. Ramakrishnan, "Leaf dynamics of tropical trees related to successional status," New Phytologist, vol. 97, no. 4, pp. 697-706, 1984.

[21] P. K. Ralhan, R. K. Khanna, S. P. Singh, and J. S. Singh, "Phenological characteristics of the tree layer of Kumaun Himalayan forests," Vegetatio, vol. 60, no. 2, pp. 91-101, 1985.

[22] Y. P. S. Pangtey, R. S. Rawal, N. S. Bankoti, and S. S. Samant, "Phenology of high-altitude plants of Kumaun in Central Himalaya, India," International Journal of Biometeorology, vol. 34, no. 2, pp. 122-127, 1990.

[23] S. N. Prasad and M. Hegde, "Phenology and seasonality in the tropical deciduous forest of Bandipur, South India," Proceedings: Plant Sciences, vol. 96, no. 2, pp. 121-133, 1986.

[24] N. Sivaraj and K. V. Krishnamurthy, "Flowering phenology in the vegetation of Shervaroys, South India," Vegetatio, vol. 79, no. 1-2, pp. 85-88, 1988.

[25] D. M. Bhat and K. S. Murali, "Phenology of understorey species of tropical moist forest of Western Ghats region of Uttara Kannada district in South India," Current Science, vol. 81, no. 7, pp. 799-805, 2001.

[26] K. P. Singh and C. P. Kushwaha, "Diversity of flowering and fruiting phenology of trees in a tropical deciduous forest in India," Annals of Botany, vol. 97, no. 2, pp. 265-276, 2006.

[27] R. K. Vashisthe, N. Rawat, A. K. Chaturvedi, B. P. Nautiyal, P. Prasad, and M. C. Nautiyal, "An exploration on the phenology of different growth forms of an alpine expanse of north-west Himalaya, India," New York Science Journal, vol. 2, pp. 29-42, 2009.

[28] V. P. Upadhyay and P. K. Mishra, "Phenology of mangroves tree species on Orissa coast, India," Tropical Ecology, vol. 51, no. 2, pp. 289-295, 2010.

[29] A. R. Kasarkar and D. K. Kulkarni, "Phenological studies of family zingiberaceae with special reference to Alpinia and Zingiber from Kolhapur region(MS) India," Bioscience Discovery, vol. 2, pp. 322-327, 2011.

[30] O. Bajpai, A. Kumar, A. K. Mishra, N. Sahu, S. K. Behera, and L. B. Chaudhary, "Phenological study of two dominant tree species in tropical moist deciduous forest from the Northern India," International Journal of Botany, vol. 8, pp. 66-72, 2012.

[31] A. Lokho and Y. Kumar, "Reproductive phenology and morphology analysis of Indian Dendrobium Sw. (Orchidaceae) from the northeast region," International Journal of Scientific and Research Publications, vol. 2, pp. 1-14, 2012.

[32] S. H. G. Champion and S. K. Seth, A Revised Survey of the Forest Types of India, The manager of Publications, Delhi, India, 1968.

[33] R. E. Sosebee and H. H. Wiebe, "Effect of phenological development on radiophosphorus translocation from leaves in crested wheatgrass," Oecologia, vol. 13, no. 2, pp. 103-112, 1973.

[34] F. G. Taylor Jr., Phenodynamics of Production in a Mesic Deciduous Forest. US/IBP Eastern Deciduous Forest Biome, Oak Ridges National Laboratory, Oak Ridge, Tenn, USA, 1972.

[35] M. Y. Nuttonson, Wheat-Climate Relationships and the Use of Phenology in Ascertaining the Thermal and Photo-Thermal
Requirements of Wheat; Based on Data of North America and Some Thermally Analogous Areas of North America, in the Soviet Union and in Finland, American Institute for Crop Ecology, Washington, DC, USA, 1955.

[36] J. P. Blaisdell, "Seasonal development and yield of native plants on the upper Snake River plains and their relation to certain climatic factors," US Department of Agriculture Technical Bulletin, vol. 1190, pp. 1-68, 1958.

[37] J. Hansen, M. Sato, R. Ruedy, K. Lo, D. W. Lea, and M. Medina-Elizade, "Global temperature change," Proceedings of the National Academy of Sciences of the United States of America, vol. 103, no. 39, pp. 14288-14293, 2006.

[38] Y. Julien and J. A. Sobrino, "Global land surface phenology trends from GIMMS database," International Journal of Remote Sensing, vol. 30, no. 13, pp. 3495-3513, 2009.

[39] A. Menzel, T. H. Sparks, N. Estrella et al., "European phenological response to climate change matches the warming pattern," Global Change Biology, vol. 12, no. 10, pp. 1969-1976, 2006.

[40] C. Parmesan and G. Yohe, "A globally coherent fingerprint of climate change impacts across natural systems," Nature, vol. 421, no. 6918, pp. 37-42, 2003.

[41] S. Piao, J. Fang, L. Zhou, P. Ciais, and B. Zhu, "Variations in satellite-derived phenology in China's temperate vegetation," Global Change Biology, vol. 12, no. 4, pp. 672-685, 2006.

[42] J. Ollerton and A. J. Lack, "Flowering phenology: an example of relaxation of natural selection?" Trends in Ecology and Evolution, vol. 7, no. 8, pp. 274-276, 1992.

[43] F. Saavedra, D. W. Inouye, M. V. Price, and J. Harte, "Changes in flowering and abundance of Delphinium nuttallianum (Ranunculaceae) in response to a subalpine climate warming experiment," Global Change Biology, vol. 9, no. 6, pp. 885-894, 2003.

[44] N. C. Stenseth and A. Mysterud, "Climate, changing phenology, and other life history traits: nonlinearity and match-mismatch to the environment," Proceedings of the National Academy of Sciences of the United States of America, vol. 99, no. 21, pp. 1337913381, 2002.

[45] I. Ibáñez, R. B. Primack, A. J. Miller-Rushing et al., "Forecasting phenology under global warming," Philosophical Transactions of the Royal Society B, vol. 365, no. 1555, pp. 3247-3260, 2010.

[46] C. Parmesan, "Influences of species, latitudes and methodologies on estimates of phenological response to global warming," Global Change Biology, vol. 13, no. 9, pp. 1860-1872, 2007. 

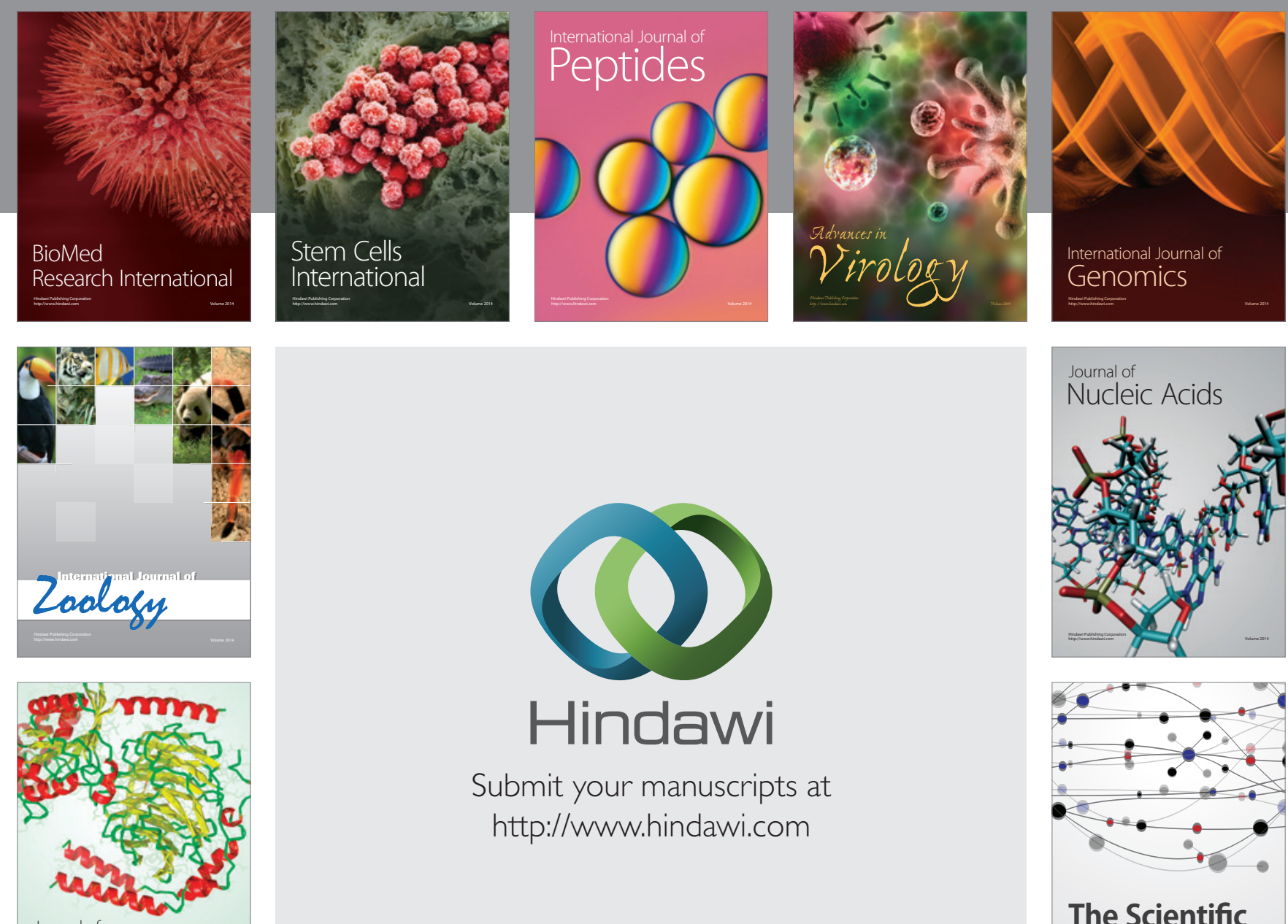

Submit your manuscripts at

http://www.hindawi.com

Journal of
Signal Transduction
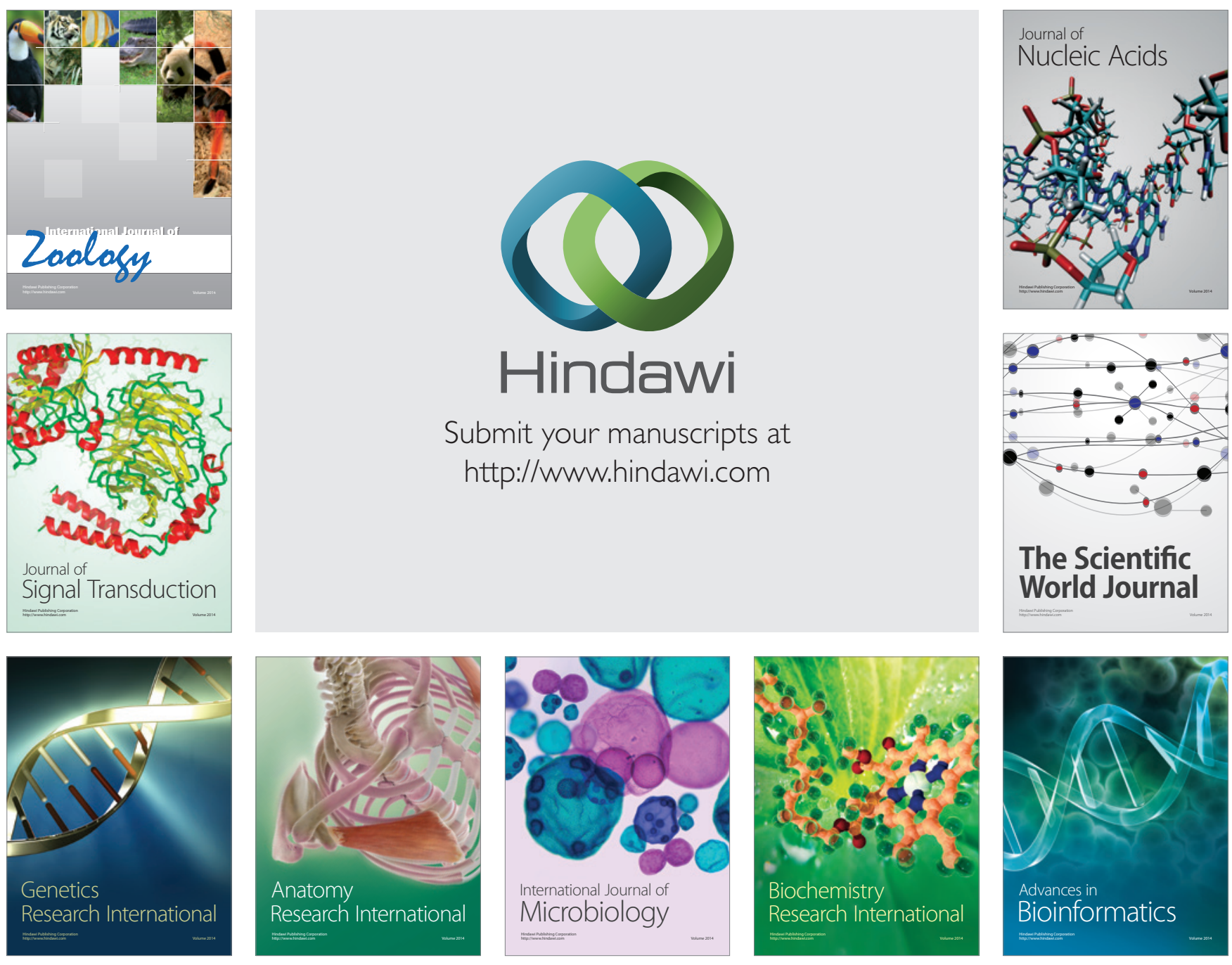

The Scientific World Journal
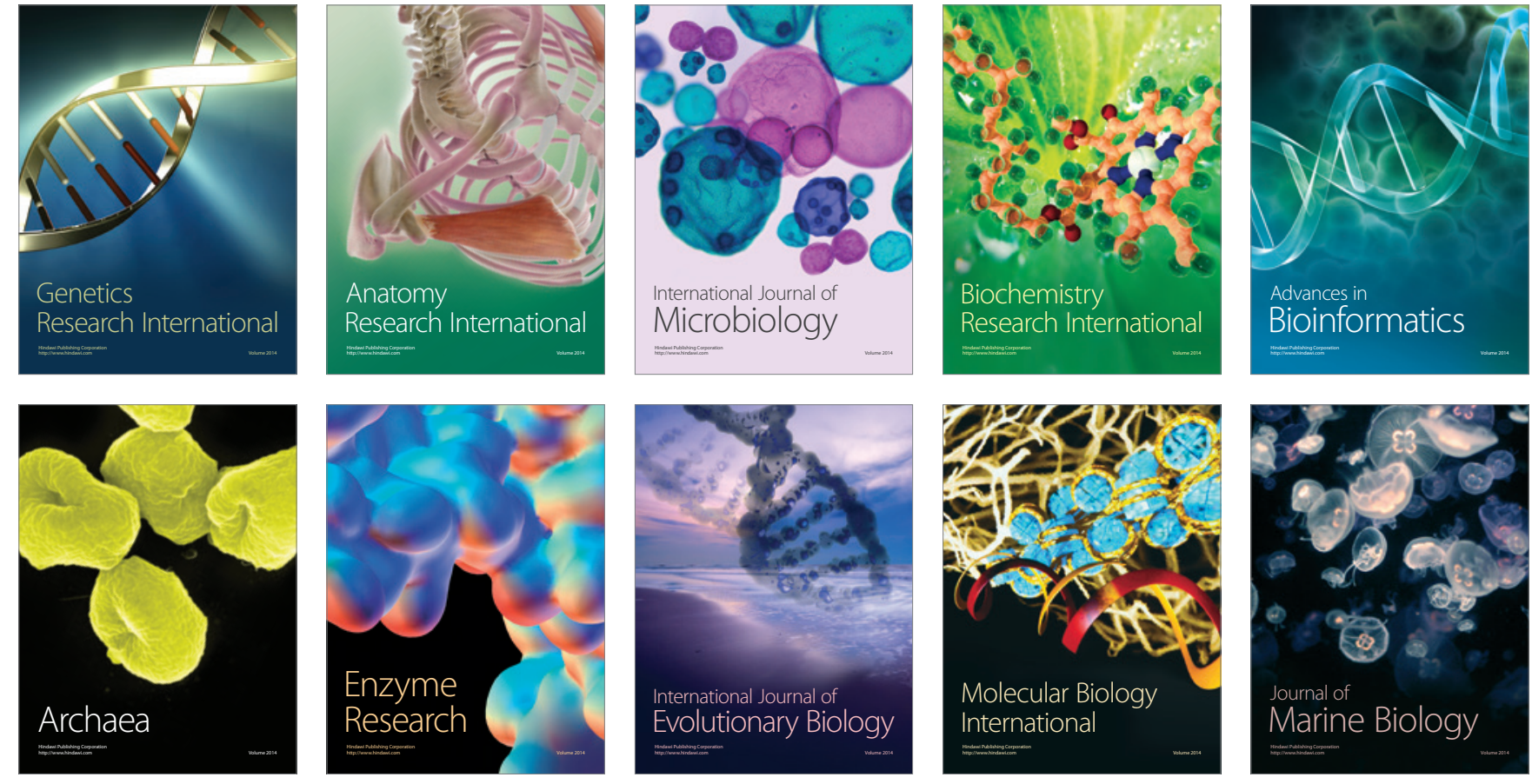